\title{
Karakteristik Kimia dan Organoleptik Kamaboko Surimi Tetelan Ikan Tuna
}

\section{Characteristics Chemical and Organoleptic of Kamaboko made of Surimi Tuna Loin Waste}

\section{Vonda M. N. Lalopua*, Aria Onsu}

\author{
Jurusan Teknologi Hasil Perikanan, Fakultas Perikanan dan Ilmu Kelautan, Universitas Pattimura, \\ Jl. Mr. Chr. Soplanit, Kampus Poka, Ambon 97233
}

*Penulis korespondensi: Vonda M.N. Lalopua, e-mail: vondamilca67@gmail.com

Tanggal submisi: 18 Maret 2021; Tanggal penerimaan: 22 Juli 2021; Tanggal publikasi: 23 Agustus 2021

\begin{abstract}
Tuna loin waste called "tetelan" is a waste of tuna loin processing, consisting of red meat and some white meat. "Tetelan" is fish meat that sticks to the bone or unused meat because of its ununiform size. This loin waste contains high protein but smells fishy. To reduce the fishy smells, "tetelan" tuna was processed to surimi kamaboko due to the steaming process and spices' addition to improving the texture properties of kamaboko carrageenan was added while surimi was processed. The research objective was to determine the effect of carrageenan concentrations on the chemical and organoleptic properties of kamaboko "tetelan" tuna. The research used an experimental method, with a single treatment named concentration of carrageenan and sago starch consisted of 3 levels of carrageenan concentration 1.0, 1.5, and 2.0\%. Kamaboko was analyzed chemically involved moisture, ash, fat and protein content, and organoleptic involved aroma, taste and texture. Organoleptic test data (aroma, taste, texture) were analyzed using the Friedman test followed by multiple comparison tests. Meanwhile, the chemical data were analyzed using a Completely Randomized Design. Data analysis showed that the concentration of carrageenan did not significantly affect the taste, aroma, and texture of kamaboko. The treatment applied significantly influenced the ash content of kamaboko. Kamaboko "tetelan" tuna showed a high protein content above the kamaboko protein quality standard.
\end{abstract}

Keywords: Carrageenan; chemical properties; organoleptic

(C) The Authors. Publisher Universitas Pattimura. Open access under CC-BY-SA license.

\begin{abstract}
ABSTRAK
Limbah hasil pengolahan tuna loin berupa tetelan ikan yang terdiri dari jenis daging merah dan sebagian daging ikan putih. Tetelan berupa daging ikan yang menempel pada tulang ikan atau daging ikan yang tidak dapat dimanfaatkan karena sayatannya yang tidak merata. Daging ikan tuna mengandung protein tinggi tetapi memiliki kelemahan berbau amis, sehingga kurang disukai konsumen. Pemanfaatan tetelan ikan tuna sebagai bahan baku surimi untuk diolah menjadi kamaboko diharapkan dapat mengurangi bau amis karena adanya proses pengukusan dan penambahan bumbu. Penambahan konsentrasi karagenan bertujuan untuk meningkatkan sifat tekstur kamaboko. Tujuan penelitian untuk mengetahui pengaruh konsentrasi karagenan terhadap sifat kimia dan organoleptik kamaboko tetelan ikan tuna. Penelitian menggunakan metode eksperimen, dengan perlakuan tunggal konsentrasi karagenan terdiri dari tiga taraf yaitu konsentrasi karagenan 1,0, 1,5, dan 2\%. Kamaboko di analisa kimia (kadar air, abu, lemak dan protein) serta organoleptik (aroma, rasa dan tekstur). Data uji organoleptik (aroma, rasa, tekstur) dianalisis mengggunakan uji Friedman dilanjutkan dengan uji perbandingan berganda. Sedangkan data kimia dianalisis dengan rancangan acak lengkap. Hasil uji Friedman menunjukkan perlakuan konsentrasi karagenan tidak berpengaruh nyata terhadap rasa, aroma dan tekstur kamaboko, sedangkan perlakuan hanya berpengaruh terhadap kadar abu kamaboko. Tetapi kadar protein kamaboko surimi tetelan tuna tinggi di atas standar mutu kamaboko.
\end{abstract}

Kata kunci: Karagenan; organoleptik; sifat-sifat kimia.

(c) Penulis. Penerbit Universitas Pattimura. Akses terbuka dengan lisensi CC-BY-SA.

(C) Penulis. Penerbit Universitas Pattimura.

Akses terbuka dengan lisensi CC-BY-SA. 


\section{PENDAHULUAN}

Atribut mutu yang penting dari kamaboko adalah sifat teksturnya yang elastis (ashi) dan faktor-faktor yang mempengaruhi ashi kamaboko diantaranya adalah jenis ikan dan bahan-bahan tambahan yang digunakan dalam pembuatan kamaboko (Mao et al., 2006). Biasanya dalam pembuatan kamaboko menggunakan surimi dari jenis ikan berdaging putih dan berprotein tinggi, sedangkan bahan tambahan (pengisi) untuk memperkuat ashi yang sering digunakan adalah pati singkong (tapioka), pati kentang, terigu, dan jagung (Mao et al., 2006; Suzuki, 1981).

Faktor utama yang mempengaruhi sifat ashi kamaboko adalah keberadaan protein ikan dan pati, dimana dapat terjadi protein ikan mengalami denaturasi karena suatu sebab, yang berpengaruh pada kekuatan gelnya oleh karena itu jika daging ikan digunakan sebagai bahan baku kamaboko diperlukan penambahan bahan lain untuk memperbaiki kekuatan gelnya, misalnya karagenan. Menurut Gomez-Guillen dan Montero (1996), menambah dan mengkombinasi hidrokoloid (iotakaragenan dan pati) dengan protein non-otot pada daging lumat ikan sardin (Sardina pilchardus) dapat meningkatkan kekuatan gel pada daging lumat berkadar garam rendah maupun tinggi. Karagenan memiliki sifat sebagai komponen pembentuk gel, penstabil dan pengental. Karagenan dapat memperbaiki tekstur dan kekenyalan produk makanan (Chairita et al., 2009).

Pembuatan kamaboko dari berbagai jenis ikan dengan penambahan konsentrasi karagenan telah banyak diteliti. Setyowati (2017) melaporkan bahwa penggunaan karagenan menghasilkan tensile strength dan tekstur yang lebih tinggi, namun kadar air rendah. Mikrostruktur kamaboko dengan menggunakan karagenan akan menghasilkan kenampakan yang berserat dan struktur yang lebih porus sehingga kamaboko akan bersifat elastis.

Menurut Sitompul et al. (2017), kamaboko dari ikan tenggiri dengan penambahan karagenan 1,5\% memiliki kualitas terbaik daripada ikan belanak dan ikan gabus dengan nilai gell strength sebesar $1370 \mathrm{~g} / \mathrm{cm}^{2}$, derajat putih 47,33\%, kadar air $68,31 \%$, kadar lemak 3,45\%, kadar protein $21,45 \%$.

Tetelan ikan adalah limbah hasil pengolahan tuna loin yang terdiri dari jenis daging merah dan sebagian daging putih. Kantun et al. (2014), menyatakan bahwa tetelan tidak dapat dimanfaatkan karena sayatannya yang tidak merata. Tetelan berupa daging ikan yang menempel pada tulang ikan dan berbau amis, sehingga kurang disukai konsumen. Untuk mengurangi bau amis tetelan ikan, perlu dilakukan diversifikasi pengolahan. Pada pengolahan dengan perlakuan pengu-kusan dan penambahan bumbu-bumbu diharapkan bau amis dapat dihilangkan sehingga tetelan ikan dapat dimanfaatkan. Salah satu pemanfaatan tetelan ikan dalam produk diversifikasi hasil olahan perikanan adalah surimi.

Hadinoto dan Idrus (2018) melaporkan bahwa daging tuna ekor kuning asal perairan Maluku memiliki kandungan gizi yang baik yaitu kadar air $71,73 \%$, kadar protein $28,34 \%$, kadar lemak $0,51 \%$. Daging ikan dengan kadar protein 'tinggi merupakan bahan baku pembuatan kamaboko yang baik. Proporsi daging putih ikan tuna lebih banyak daripada daging merahnya. Daging putih berkisar antara 80-100\% dari keseluruhan daging ikan. Lanier (1992) menyatakan bahwa bahan baku kamaboko yang baik berasal dari surimi yang memiliki warna putih, rasa yang baik (khas ikan) dan memiliki kemampuan gel yang kuat. Surimi yang baik biasanya terbuat dari bahan baku yang segar dan bahan baku yang sering digunakan meskipun tersedia dalam jumlah besar tetapi memiliki nilai ekonomis yang rendah.

Peneliti tertarik untuk memanfaatkan tetelan ikan tuna sebagai bahan baku surimi untuk diolah menjadi kamaboko dengan penambahan karagenan. Tujuan penelitian untuk mengetahui pengaruh penambahan konsentrasi karagenan terhadap karakteristik kimia dan organoleptik kamaboko tetelan ikan tuna.

\section{METODE PENELITIAN}

\section{Bahan}

Bahan yang digunakan adalah tetelan ikan tuna beku yang diperoleh dari PT. Harta Samudra, Tantui, Ambon dan langsung di bawa ke laboratorium Teknologi Hasil Perikanan, Fakultas Perikanan dan Ilmu Kelautan, Universitas Pattimura. Jarak menuju laboratorium ditempuh dalam waktu 15 menit, dan selanjutnya disimpan dingin selama dua hari sebelum diolah menjadi surimi dan kamaboko.

\section{Prosedur Penelitian}

Penelitian diawali dengan pembuatan surimi dari tetelan ikan tuna, dilanjutkan dengan pembuatan kamaboko menggunakan konsentrasi kara- 
genan kemudian kamaboko di analisa kimia dan organoleptik.

\section{Prosedur pembuatan surimi}

Pembuatan surimi tetelan ikan tuna menurut metode Suzuki (1981) yang dimodifikasi dengan tahapan sebagai berikut: tetelan tuna dicuci menggunakan air dingin, setelah itu daging dilumatkan menggunakan food processor (Mitochiba, Indonesia) selama 1 menit low speed dan 1 menit high speed. Selama penggilingan tetelan ditambahkan hancuran es batu untuk mempertahankan suhu rendah. Lumatan daging ikan dicuci dengan air dingin $\left(5-10^{\circ} \mathrm{C}\right)$ sebanyak tiga kali dan ditambahkan $\mathrm{NaCl} 0,1 \%$ (Merck, Jerman) pada pencucian terakhir. Lumatan daging ikan disaring menggunakan kain saring dan dipress secukupnya.

\section{Prosedur Pembuatan Kamaboko}

Garam (Dolpin, Indonesia) sebanyak 2\% ditambahkan pertama kali untuk mengekstrak protein aktomiosin sehingga terbentuk pasta sol aktomiosin. Lalu tambahkan pati sagu (5\%) dan karagenan (Indogum, Indonesia) sesuai perlakuan yaitu konsentrasi 1,0, 1,5 dan 2\%. Pencampuran bahan dilakukan menggunakan food processor high speed 1 menit, selama penggilingan ditambahkan hancuran es $20 \%$ agar suhu tetap rendah. Adonan kamaboko yang telah homogen kemudian di bungkus dengan kertas alumunium foil selanjutnya adonan dikukus pada suhu $90^{\circ}-95^{\circ} \mathrm{C}$ selama 30 menit. Setelah dikukus, kamaboko didinginkan dengan direndam dalam air es untuk menghindari over cooking. Kamaboko yang telah dingin dipotong dan dilakukan analisa kimia dan orrganoleptik.

\section{Parameter uji}

Parameter yang diuji dalam penelitian ini adalah: kadar air (metode termogravimetri), kadar abu (metode pengabuan kering), kadar lemak (metode Soxhlet), dan kadar protein (metode Kjedhal) menurut AOAC (2005) dan uji organoleptik (aroma, rasa, tekstur) diuji oleh panelis sebanyak 15 orang menggunakan score sheet skala 1-5.

\section{Analisa Data}

Data hasil analisa kimia (kadar air, abu, lemak, protein) dianalisis menggunakan rancangan acak lengkap dengan enam kali ulangan dan jika perlakuan berpengaruh nyata, dilanjutkan dengan uji Tukey. Sedangkan data hasil uji organoleptik (aroma, rasa, tekstur) dianalisis mengggunakan uji Friedman (Wayne, 1989).

\section{HASIL DAN PEMBAHASAN}

\section{Kimia Kamaboko}

\section{Kadar Air}

Histogram kandungan kimia (kadar air, abu, lemak dan protein) kamaboko perlakuan konsentrasi karagenan disajikan pada Gambar 1 .

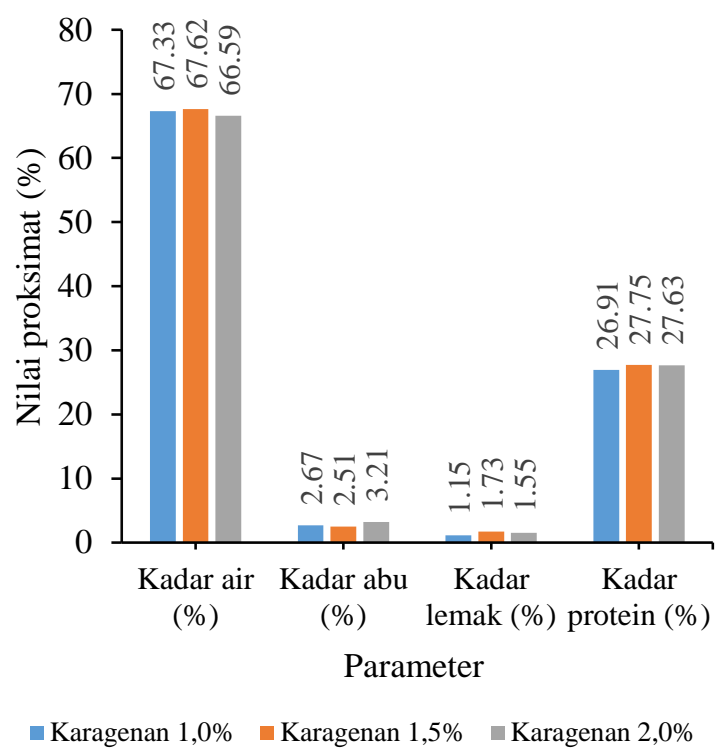

Gambar 1. Kandungan kimia kamaboko surimi tetelan tuna dengan perlakuan konsentrasi karagenan

Hasil analisis keragaman menunjukkan bahwa perlakuan tidak berpengaruh nyata terhadap kadar air kamaboko. Hasil rataan perlakuan kadar air kamaboko berkisar antara 66,59-67,33\%. Kamaboko dengan penambahan karagenan 2\% yang merupakan konsentrasi karagenan tertinggi menghasilkan kadar air terendah. Secara umum penambahan konsentrasi karagenan dapat menurunkan kadar air kamaboko karena karagenan adalah hidrokoloid sehingga dapat menyerap air. Mastuti (2008) melaporkan bahwa penambahan karagenan telah menurunkan kadar air sampel dibandingkan dengan kontrol. Penurunan kadar air oleh karagenan disebabkan oleh gugus hidrofil yang berikatan kuat dengan molekul air di dalam sistem emulsi daging. Menurut Park (2005) karagenan mampu mengikat 
air dengan kuat sehingga air akan sulit keluar dari matrik protein. Interaksi karagenan dengan air terjadi melalui ikatan hidrogen yaitu air dengan gugus hidroksil disepanjang rantai karagenan. Oleh karena itu semakin tinggi penambahan konsentrasi karagenan maka kemampuan mengikat air oleh kamaboko meningkat. Sitompul et al. (2017), menunjukkan bahwa nilai kadar air dari kamaboko dengan penambahan karagenan lebih rendah bila dibandingkan dengan kamaboko tanpa penambahan karagenan.

Kadar air kamaboko bersumber dari surimi daging ikan yang telah mengalami penurunan karena proses pengukusan. Semakin tinggi suhu dan lama waktu pengukusan maka kadar air akan menurun.

\section{Kadar Abu}

Kandungan bahan organik dan air dari sebagian besar makanan hampir mencapai $96 \%$ dan sisanya terdiri dari unsur-unsur mineral. Unsur mineral dikenal sebagai zat organik, yang dalam proses pembakaran akan terbakar tetapi zat-zat organiknya tidak yang disebut abu. Menurut Winarno (2002), tujuan analisa kadar abu untuk mengetahui baik tidaknya pengolahan, mengetahui jenis bahan yang digunakan, penentuan parameter nilai gizi suatu makanan dan memperkirakan kandungan dan keaslian bahan yang digunakan..

Hasil rataan kadar abu kamaboko berkisar antara 2,51-3,51\%. Kadar abu perlakuan cenderung meningkat dengan penambahan konsentrasi karagenan. Hasil analisa keragaman menunjukkan perlakuan berpengaruh nyata $(P<0,05)$ terhadap kadar abu kamaboko. Hasil uji Tukey menunjukkan bahwa perlakuan karagenan 1,0\% tidak berbeda nyata terhadap perlakuan karagenan 2,0\% tetapi berbeda nyata dengan perlakuan karagenan $1,5 \%$.

Kadar abu kamaboko perlakuan karagenan 2,0\% sebesar 2,9 $\pm 0,00$, memenuhi standar mutu. Karagenan adalah bahan organik jika dibakar akan menyisakan abu. Pada proses pemasakan (pengukusan) dalam pengolahan kamaboko mengakibatkan sebagian air hilang sehingga meningkatkan kandungan mineral bahan.

Penelitian Wirawati (2017) menunjukkan adanya peningkatan kadar abu kamaboko ikan kembung (Rastreliger sp.) secara linier dengan penambahan konsentrasi karagenan $(0,0,2,5,5,0$, 7,5 dan 10\%). Peningkatan kadar abu kamaboko terkait dengan kandungan mineral $\mathrm{Ca}$ dan $\mathrm{Fe}$, natrium, serta magnesium dan kalium dari karagenan yang dapat terikat dengan gugus ester sulfat galaktosa dan 3,6-anhidro-galaktosa (Peranginangin dan Yunizal, 2000). Kandungan abu karagenan yang tinggi umumnya ditemukan pada jenis kappa karagenan (Sidi et al., 2014).

\section{Kadar Lemak}

Keberadaan lemak dalam bahan makanan memiliki sifat fungsional yang dapat mempengaruhi warna, flavour, tekstur, kelembutan serta emulsifikasi. Hasil rataan nilai kadar lemak kamaboko perlakuan konsentrasi karagenan berkisar 1,15$1,73 \%$. Kadar lemak tertinggi diperoleh dari konsentrasi karagenan $1,5 \%$ dengan nilai 1,73 sedangkan kadar lemak terendah di peroleh dari konsentrasi karagenan $1 \%$ dengan nilai 1,15.

Hasil analisis keragaman menunjukan bahwa penambahan karagenan tidak berpengaruh nyata tehadap kadar lemak kamaboko. Sitompul et al. (2017) melaporkan bahwa tidak ada pengaruh penambahan karagenan pada kamaboko yang menggunakan daging ikan belanak, ikan gabus dan ikan tenggiri yang diakibatkan oleh sifat hidrofilik karagenanan yang suka mengikat air dari pada lemak. Ariyani (2005) juga menyatakan bahwa karagenan lebih berfungsi untuk mengikat air daripada mengikat lemak. Dalam lemak, karagenan tidak bisa larut tetapi karagenan dapat berikatan dengan protein, dan lemak akan diikat oleh kutub positif protein. Oleh karena itu penambahan karagenan akan meningkatkan daya ikat air oleh protein dan menurunkan daya ikat protein terhadap lemak.

Kadar lemak daging tuna lebih tinggi daripada karagenan, oleh karena itu penambahan karagenan menyebabkan proporsi daging ikan dalam adonan makin sedikit sehingga kadar lemak semakin rendah.

\section{Kadar Protein}

Histogram (Gambar 1) menunjukkan kadar protein kamaboko ikan tuna berkisar (26,91$27,75 \%$ ). Kadar protein kamaboko tetelan ikan tuna lebih tinggi dari standar mutu protein kamaboko sebesar 12,1\% (Ramos et al., 2012). Kadar protein tertinggi diperoleh pada perlakuan konsentrasi karagenan 2,0\%. Hasil penelitian menunjukkan bahwa pada perlakuan karagenan 1,0 dan $1,5 \%$ nilai protein naik tetapi kemudian turun pada perlakuan karagenan 2,0\%. Kadar protein kamaboko yang tinggi bersumber dari protein daging tuna dan karagenan. Hadinoto dan Idrus (2018) melaporkan bahwa kadar protein daging tuna sebesar $28,34 \%$, 
sedangkan kadar protein karagenan sebesar 2,80\% menurut Murdinah (2008).

Hasil analisa ragam menunjukan bahwa penambahan karagenan tidak berpengaruh nyata terhadap kadar protein kamaboko. Ramos et al. (2012) dan Wirawati (2017) juga melaporkan bahwa semakin tinggi konsentrasi karagenan yang digunakan maka kadar protein kamaboko cenderung menurun. Karagenan dapat berikatan dengan protein, sehingga kadar protein kamaboko turun. Menurut Abubakar et al. (2011), karagenan dapat berikatan dengan protein menjadi proteo-karagenat sehingga memperbesar luas permukaan yang dapat menyerap atau mengikat air. Agustin (2012) menjelaskan bahwa interaksi karagenan dan protein terjadi melalui ikatan elektrostatik yaitu muatan negatif gugus sulfat karagenan dan muatan positif sisi samping asam amino pada permukaan miofibril protein. Oleh karena itu semakin tinggi penambahan tepung karagenan yang diberikan pada suatu produk maka kadar proteinnya semakin turun.

\section{Nilai Organoleptik}

\section{Nilai Aroma}

Hasil rataan nilai organoleptik kamaboko tetelan ikan tuna (Thunnus alabacares) dengan penambahan konsentrasi karagenan berkisar 3,4-4,0 untuk nilai aroma, nilai tekstur berkisar 3,86-4,00 dan nilai rasa berkisar 3,36-3,60 (Gambar 2). Perlakuan konsentrasi karagenan 1,0\% dan 1,5\% dihasilkan kamaboko dengan spesifikasi aroma amis dan tengik, perlakuan karagenan 2,0\% spesifikasi aroma agak amis dan agak tengik.

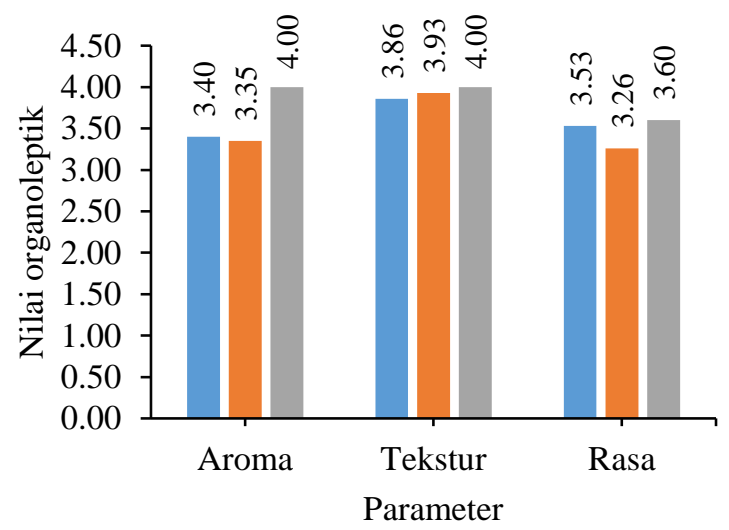

- Karagenan $1,0 \% \quad$ Karagenan $1,5 \% \quad$ Karagenan 2,0\%

Gambar 2. Nilai organoleptik kamaboko surimi tetelan tuna dengan perlakuan konsentrasi karagenan
Umumnya daging ikan tersusun oleh dua jenis daging yaitu daging merah dan putih. Daging merah ditemukan hanya di sepanjang tubuh bagian samping dibawah kulit sedangkan daging putih terdapat di seluruh bagian tubuh ikan. Baik daging merah maupun daging putih sangat rentan terhadap serangan oksidatif. Keberadaan kromoprotein seperti hemoglobin dan mioglobin yang berperan sebagai fotosensitizer serta lipid dan glikogen maupun kelompok enzim metabolik aerobik, asam amino penyusun protein yang mudah teroksidasi (triptofan, histidin, tirosin, sistein, metionin, dan lisin) maupun beberapa asam amino lainnya yang terdapat baik pada daging merah maupun putih, merupakan faktor-faktor yang berpengaruh terhadap rentannya protein daging terserang radikal pengoksidasi (Sikorsi, 1990). Apituley (2007) menyatakan bahwa protein daging merah lebih rentan terhadap serangan radikal hidroksil yang dihasilkan dari katalis logam $\mathrm{CuSO}_{4} / \mathrm{H}_{2} \mathrm{O}_{2}$.

Kadar protein daging putih lebih tinggi, tetapi daging merah, kadar lemak lebih tinggi. Ikan yang mengandung lemak tinggi sangat mudah teroksidasi dan akan menghasilkan bau dan aroma tengik. Pada pembuatan kamaboko, bau tengik sukar dihilangkan dengan proses pengukusan dan penambahan bumbu.

Hasil uji Friedman nilai aroma menunjukkan nilai $\chi_{\mathrm{i}}{ }^{2}$-hitung sebesar 4 dan lebih besar dari nilai $\chi_{i}{ }^{2}$-Tabel $(0,05)$ artinya perlakuan konsentrasi karagenan yang digunakan untuk pembuatan kamaboko tidak berpengaruh nyata terhadap aroma kamaboko.

Hasil yang diperoleh sesuai dengan penelitian Wirawati (2017) bahwa aroma kamaboko tidak dipengaruhi oleh konsentrasi karagenan yang di tambahkan. Kamaboko tanpa penambahan karagenan maupun dengan penambahan karagenan konsentrasi 2,5, 5,0, 7,5, dan 10\% juga tidak menunjukkan pengaruh nyata terhadap nilai aroma. Menurut Herawati (2008), hidrokoloid pada umumnya tidak mengandung bahan-bahan volatil yang mempengaruhi aroma dan warna pada bahan pangan. Hidrokoloid hanya dapat menimbulkan efek sinergis terhadap cita rasa ke dalam emulsi.

Kamaboko yang baik harus memiliki aroma daging ikan. Aroma kamaboko sangat dipengaruhi oleh kesegaran daging ikan yang bersumber dari asam amino atau peptida pembentuk rasa/flavour. Anwar et al. (2019) melaporkan bahwa faktor jenis ikan dan konsentrasi tepung terigu memberikan pengaruh tidak nyata terhadap aroma kamaboko, artinya semua kamaboko yang dihasilkan dengan 
perlakuan jenis ikan yang berbeda dengan penambahan tepung terigu pada konsentrasi yang sama memiliki tingkat kesukaan aroma yang cenderung sama terhadap kamaboko yang dihasilkan. Fardiaz (1985) menyatakan bahwa aroma kamboko dipengaruhi oleh bau amis ikan yang telah berkurang karena proses pencucian daging ikan dengan air dingin karena dapat menghilangkan lemak, darah, pigmen, lendir serta protein yang larut dalam air.

\section{Nilai Tekstur}

Karakteristik yang sangat penting bagi produk gel ikan adalah sifat elastisitas dan kekenyalan tekstur. Histogram organoleptik kamaboko menunjukkan nilai tekstur kamaboko meningkat dengan penambahan konsentrasi karagenan. Nilai tekstur kamaboko untuk perlakuan konsentrasi $1,0,1,5$, dan $2,0 \%$ masing masing sebesar 3,86, 3,93 dan 4,00.

Hasil uji Friedman tekstur kamaboko menunjukkan bahwa nilai $\chi_{i}{ }^{2}$-hitung sebesar 4 dan nilai tersebut lebih kecil dari nilai $\chi_{i}{ }^{2}$-tabel $(0,05)$ sebesar 5,99. Oleh karena itu perlakuan yang diberikan tidak berpengaruh nyata terhadap nilai tektur kamaboko.

Hasil yang diperoleh berbeda dengan hasil penelitan Wirawati (2017) yang menggunakan konsentrasi karagenan 0,0, 2,5, 5,0, 7,5 dan 10,0\% untuk pembuatan kamaboko dari surimi ikan kembung menunjukkan hasil tidak berpengaruh nyata terhadap organoleptik warna, bau dan rasa tetapi berpengaruh nyata terhadap tekstur. Dilaporkan bahwa pada penambahan konsentrasi tepung karagenan 5\% diperoleh nilai tekstur kekenyalan kamaboko sebesar 6,62\%. Berdasarkan hasil penelitian Wirawati (2017), diduga bahwa akibat penggunaan konsentrasi karagenan terlalu rendah (2\%) menyebabkan tidak berpengaruh terhadap tekstur kamaboko. Hasil spesifikasi tekstur dari perlakuan karagenan $2 \%$ sedikit lebih baik dari perlakuan konsentrasi 1 dan $1,5 \%$, yaitu agak kenyal, agak kompak, dan padat sedangkan pada perlakuan konsentrasi $1 \%$ dan $1,5 \%$ spesifikasi tekstur kamaboko tidak kenyal, kompak dan padat.

Sifat elastis kamaboko sangat dipengaruhi oleh keberadaan daging putih dan denaturasi protein. Pada pengolahan kamaboko denaturasi protein terjadi karena proses pemasakan. Denaturasi protein mulai berlangsung sejak proses thawing tetelan dan berlanjut pada pembuatan surimi. Denaturasi protein akan menjadi lebih besar jika tidak digunakan cryoprotectant. Hal ini akan berpengaruh terhadap tekstur kamaboko.

Pada proses pencucian daging ikan lumat dengan air atau larutan garam dapat terjadi kehilangan sebagian besar komponen yang larut dalam air, darah (pigmen), komponen penyebab bau pada lemak, protein larut air dan garam seperti protein sarkoplasma (Abdurachman, 1987). Adanya protein sarkoplasma dalam pembuatan kamaboko akan mempengaruhi proses pembentukan gel menjadi tidak elastis karena selama pemanasan protein ini mengalami koagulasi dan melekat pada protein miofibrilar (Anjasari, 2010).

Menurut Anjarsari (2010) ikan demersal sangat baik digunakan sebagai bahan baku pembuatan surimi. Lanier (1992) menyatakan bahwa surimi dari bahan baku segar memiliki kemampuan gel yang kuat. Menurut Rostini (2013) pembentukan gel dipengaruhi oleh tingkat kesegaran ikan dan $\mathrm{pH}$ daging. Kekuatan gel berkaitan dengan $\mathrm{pH}$ ikan, kekuatan gel meningkat jika $\mathrm{pH}$ daging berkisar antara 6,0-7,0.

Anjarsari (2010) menyatakan bahwa proses pemanasan menyebabkan terjadinya pembentukan gel. Pada pemanasan adonan (sol aktomiosin) akan berubah menjadi gel suwari. Selanjutnya pada suhu $60^{\circ} \mathrm{C}$ tejadi pelunakan gel dan pada suhu diatas $70^{\circ} \mathrm{C}$ terbentuk gel kamaboko (ashi) yang kenyal dan elastis. Putra et al. (2015) menyatakan bahwa kandungan aktin dan miosin yang tinggi pada protein akan membantu dalam proses pembentukan matriks gel yang kuat sehingga tekstur yang terbentuk akan semakin kenyal, kompak serta padat.

Tekstur bahan pangan juga dipengaruhi oleh kadar air dan aktivitas air (Hidayat et al., 2014). Kadar air rendah sangat baik untuk meningkatkan nilai tekstur kamaboko. Kadar air kamaboko tetelan ikan tuna berkisar 66,59-67,33\%. Rendahnya konsentrasi karagenan yang digunakan bersama dengan konsentrasi pati sagu $5 \%$ diduga sebagai faktor penyebab perlakuan tidak berpengaruh terhadap tekstur kamaboko.

Bahan baku yang digunakan untuk pembuatan surimi harus berkualitas. Menurut Park (2005), daging giling yang digunakan untuk pembuatan surimi sebaiknya memiliki diameter 3 $\mathrm{mm}$ hingga $5 \mathrm{~mm}$. Sebelum daging di-press, daging harus dibersihkan dari tulang, kulit dan darah. Ukuran dan tekstur dari daging giling ikan juga akan memberikan pengaruh pada kualitas minced fish. 


\section{Nilai Rasa}

Hasil uji Friedman yang dilanjutkan uji perbandingan berganda menunjukkan bahwa nilai rasa kamaboko untuk perlakuan konsentrasi karagenan $1,0 \%, 1,5 \%$, dan $2,0 \%$ adalah sebesar 3,53, 3,26 dan 3,60. Dari hasil yang diperoleh dapat dilihat bahwa nilai $\chi_{i}{ }^{2}$-hitung sebesar 4 dan nilai 4 ini lebih besar dari nilai $\chi_{i}{ }^{2}$-tabel $(0,05)$ sebesar 5,99. Dengan demikian perlakuan yang diberikan tidak berpengaruh nyata terhadap nilai rasa kamaboko. Hasil penelitian sesuai dengan Wirawati (2017), yang menggunakan konsentrasi karagenan 0,0, 2,5, $5,0,7,5$ dan 10,0\% menunjukkan hasil tidak berpengaruh nyata terhadap nilai rasa kamaboko ikan kembung.

Kamaboko yang baik harus memiliki rasa ikan, tetapi rasa ikan dapat berkurang dengan penambahan konsentrasi karagenan. Menurut Sihmawati dan Salasa, (2014), karagenan tidak memberikan pengaruh terhadap rasa kamaboko karena tepung karagenan tidak memiliki rasa. Yamaguchi dan Watanabe, (1990) menyatakan bahwa senyawa yang berperan terhadap rasa kamaboko berasal dari asam amino bebas daging ikan meliputi asam glutamat, glisin, alanin, arginin, metionin, valin dan prolin.

\section{KESIMPULAN}

Kamaboko dari surimi tetelan tuna mengunakan konsentrasi karagenan 1,0-2,0\% menunjukkan tidak berpengaruh nyata terhadap karakteristik kimia (kadar air, kadar lemak dan kadar protein) maupun nilai organoleptik (aroma, tekstur dan rasa) tetapi berpengaruh nyata terhadap kadar abu. Kamaboko dengan perlakuan konsentrasi karagenan 2,0\% memenuhi standar mutu kadar abu. Kamaboko surimi tetelan tuna dengan perlakuan konsentrasi karagenan 1,0-2,0\% menghasilkan kadar protein di atas standar mutu. Kadar protein kamaboko tertinggi sebesar 27,75\% menggunakan konsentrasi karagenan 1,5\%.

\section{DAFTAR PUSTAKA}

Abdulrahman, 1987. Teknologi pengolahan surimi. Balai Bimbingan dan Pengujian Mutu Hasil Perikanan, Jakarta

Abubakar, T. Suryati, dan A. Azizs. 2011. Pengaruh penambahan karagenan terhadap sifat fisik, kimia dan palatabilitas nugget daging itik lokal (Anas platyrynchos). Seminar Nasional Teknologi Peternakan dan Veteriner.

Agustin, T.I. 2012. Mutu fisik dan mikrostruktur kamaboko ikan kurisi (Nemipterus nematophorus) dengan penambahan karagenan. Jurnal Pengolahan Hasil Perikanan Indonesia 15: 17-26.

Anwar, C., I.R. Aprita, dan Irmayanti. 2019. Kajian penggunaan jenis ikan dan tepung terigu terhadap kualitas kimia, fisik dan organoleptik kamaboko. Journal of Fisheries and Marine Research 3: 288-300.

Anjarsari, B. 2010. Pangan Hewani Fisiologi Pasca Mortem dan Teknologi. Yogyakarta: Graha Ilmu.

Apituley, D.A.N. 2007. Oksidasi Daging Tongkol Putih (Thunnus sp.). Disertasi. Sekolah Pascasarjana, Universitas Gajah Mada.

Association of Official Analytical Chemist [AOAC]. 2005. Official Methods of Analysis (18 Edn). Association of Official Analytical Chemist Inc. Mayland. USA.

Ariyani, F. 2005. Sifat Fisik dan Palatabilitas Sosis Daging Sapi dengan Penambahan Karagenan. Departemen Ilmu Produksi Ternak. Fakultas Peternakan, IPB. Bogor. Diakses pada 4 September 2016.

Chairita, L. Hardjito, J. Santoso, dan Santoso. 2009. Karakteristik bakso ikan dari campuran surimi ikan layang (Decapterus spp.) dan ikan kakap merah (Lutjanus sp.) pada penyimpanan suhu dingin. Jurnal Pengolahan Hasil Perikanan Indonesia 12: 46-58.

Fardiaz, D. 1985. Kamaboko, produk olahan ikan yang berpotensi untuk dikembangkan. Media Teknologi Pangan 1: 50-67

Gomez-Guillen, M.C. and P. Montero. 1996. Addition of hydrocolloids and non-muscle proteins to sardine (Sardina pilchardus) mince gels: Effect of salt concentration. Food Chemistry 56: 421-427. DOI: https://doi.org/ 10.10160308-8146995000211-1)

Hadinoto, S. dan S. Idrus. 2018. Proporsi dan kadar proksimat bagian tubuh ikan tuna ekor kuning (Thunnus albacares) dari perairan Maluku. Majalah BIAM 14: 51-57

Herawati, H. 2005 Penentuan umur simpan pada produk pangan. Jurnal Litbang Pertanian 27: 124-130.

Hidayat, N., M. Ilza, dan Syahrul. 2014. Kajian penggunan rumput laur Eucheuma cottonii sebagai bahan tambahan dalam pengolahan 
kamaboko ikan patin (Pangasius hypopthalmus). Jurnal Perikanan dan Kelautan 19: 33-41.

Kantun, W., A. Mallawa, dan N.L. Rapi. 2014. Struktur ukuran dan jumlah tangkapan tuna Madidihang (Thunnus albacares) menurut waktu penangkapan dan kedalaman di perairan Majene Selat Makassar. Jurnal Saintek Perikanan Universitas Hasanuddin 9: 39-48.

Kusumamurini, P. 2013. Pengaruh Penambahan Modified Strach Terhadap Mutu Kamaboko Surimi Ikan Mas. Skripsi. Jurusan Perikanan Fakultas Pertanian Universitas Gadjah Mada.

Lanier, T.C. 1992. Measurement of Surimi Composition and Fuctional Properties. In: Lanier, T.C., C.M. Lee (Editors). Surimi Technology. New York: Marcel.

Mao, W., F. Mika, and F. Noboru. 2006. Gel strength of kamaboko gels produced by microwave heating. Food Science and Technology Research 12: 241-246.

Mastuti, R. 2018. Formulasi konsentrasi bahan pengikat produk daging kambing tetelan restrukturisasi mentah. Jurnal Ilmu dan Teknologi Hasil Ternak 3: 15-23.

Murdinah. 2008. Pengaruh Bahan Pengekstrak Dan Penjendal Terhadap Mutu Karagenan Dari Rumput Laut Eucheuma cottonii. Prosiding Seminar Nasional Tahunan V Hasil Penelitian Perikanan dan Kelautan tahun 2008. Jilid 3. Kerjasama Jurusan Perikanan dan Kelautan UGM dengan Balai Dasar Riset Pengolahan Produk dan Bioteknologi Kelautan dan Perikanan.

Park, J.W. 2005. Surimi gel colors as affected by moisture content and physical condition. Jurnal Food Science 60: 15-18.

Peranginangin, R. dan Yunizal. 2000. Teknologi Ekstraksi Pikoloid dari Rumput Laut. Hlm 135-154. Dalam: R. Rachmat, Sulistijo dan A.Rasyid (Eds). Prosiding Pra Kipnas VII Forum Komunikasi Ikatan Fikologi Indonesia, 8 September 1999.

Pudyastuti, A.N., A.S. Darmanto, dan F. Swastawati. 2011. Analisa mutu satsuma age ikan kurisi (Nemipterus sp) dengan penggunaan jenis tepung berbeda. Jurnal Saintek Perikanan 6: 13 -22.

Putra, D.A.P., T.W. Agustini, dan I. Wijayanti. 2015. Pengaruh penambahan karagenan sebagai stabilizer terhadap karakteristik otakotak ikan kurisi (Nemipterus nematophorus).
Jurnal Pengolahan dan Bioteknologi Hasil Perikanan 4: 1-10.

Ramos, L. R.O., N. Choi, and H. Ryu. 2012. Effects of processing condition on the protein quality of fried anchovy kamboko Engraulis japonica. Journal Fisheries and Aquatic Science 15: 265-273. DOI: 10.5657/FAS.2021.0265

Rostini, L. 2013. Pemanfaatan daging limbah filet ikan kakap merah sebagai bahan baku surimi untuk produk perikanan. Jurnal Akuatika 4: 141-148.

Setyowati, E. 2017. Karakteristik Mutu Fisikokimia dan Sensori Kamaboko Ikan Lemuru (Sardinella sp.) dengan Variasi Jenis Bahan Pengikat. Skripsi. Jurusan Teknologi Hasil Pertanian Fakultas Teknologi Pertanian Universitas Jember.

Sidi, N.C., E., Widowati, dan A. Nursiwi. 2014. Pengaruh penambahan karagenan pada karakteristik fisikokimia dan sensoris fruit leather nanas (Annanas Comosus L. Merr) dan wortel (Daucus Carota). Jurnal Aplikasi Teknologi Pangan 3: 122-127.

Sihmawati, R.R. dan M.N. Salasa. 2014. Aspek mutu dan tingkat kesukaan konsumen terhadap surimi ikan belut. Jurnal Agroknow 2: 59-70.

Sikorsi, Z.E. 1990. Seafood: Resource, Nutritional Composition and Preservation. Florida: CRC Press Inc., Boca Rotan.

Sitompul, R., Y.S. Darmanto, dan R. Romadhon. 2017. Aplikasi karagenan terhadap kekuatan gel pada produk kamaboko dari ikan. Jurnal Pengolahan dan Bioteknologi Hasil Perikanan 6: 15-26.

Suryono, M., Harojono, dan Yunianta. 2013. Pemanfaatan ikan tuna (Yellowfin tuna), ubi jalar (Ipomea batatas) dan sagu (Metroxylon sago) dalam pembuatan kamaboko. Jurnal Teknologi Pertanian 141: 9-20.

Wayne, D. 1989. Statistik Non Parametrik Terapan. Penerjemah Alex Tri Kunntjoro. Jakarta: PT. Gramedia.

Winarno, F.G. 2002. Kimia Pangan dan Gizi. Jakarta: Gramedia Pustaka Utama.

Wirawati, N.R. 2017. Pengaruh Penambahan Tepung Karagenan Terhadap Sifat Fisik, Sifat Kimia, dan Organoleptik pada Produk Kamaboko Ikan Kembung (Rastrelliger sp.). Fakultas Perikanan dan Ilmu Kelautan Universitas Brawijaya Malang. 
Yamaguci, K. and K. Watanabe. 1990. Taste Active Component Of Fish And Shellfish. In: Motohiro, T., H. Kadota, K. Hasimoto, M. Kayama, T. Tokunaga (Editors). Science of Processing Marine Products Vol 1. Hyogo
International Centre: Japan International Cooperation Agency.

Suzuki, T. 1981. Fish and Krill Protein: Processing Technology. London: Applied Science Publisher, Ltd. 